\title{
Laminin and $\alpha$-Dystroglycan Mediate Acetylcholine Receptor Aggregation via a MuSK-Independent Pathway
}

\author{
Federica Montanaro, ${ }^{1}$ Stephen H. Gee, ${ }^{2}$ Christian Jacobson, ${ }^{1}$ Michael H. Lindenbaum, ${ }^{1}$ Stanley C. Froehner, ${ }^{2}$ \\ and Salvatore Carbonetto ${ }^{1}$ \\ ${ }^{1}$ Centre for Research in Neuroscience, McGill University, Montreal General Hospital Research Institute, Montreal, Canada \\ H3G 1A4, and 2Department of Physiology, University of North Carolina at Chapel Hill, Chapel Hill, \\ North Carolina, 27599-7545
}

\begin{abstract}
Specific isoforms of laminin (LN) are concentrated at neuromuscular junctions (NMJs) where they may participate in synaptic organization or function. In myotubes from C2 cells, LN is concentrated within the majority of spontaneous acetylcholine receptor (AChR) aggregates. Neural agrin substantially increases this colocalization, suggesting that agrin can recruit $L N$ into $A C h R$ aggregates. Addition of $L N$ to $\mathrm{C} 2$ myotubes induces a more than twofold increase in the number of AChR aggregates. These aggregates have a larger size and are more dense than are those induced by agrin, suggesting that $L N$ is involved in the growth and/or stabilization of AChR aggregates. Consistent with this hypothesis, an antiserum to LN reduces the size of individual AChR aggregates but increases their number. In C2 myotubes, extracellular matrix receptors containing the integrin $\beta 1$ subunit are poorly colocalized with AChR aggregates, suggesting that integrins may not be involved in $\mathrm{LN}$-induced
\end{abstract}

aggregation. In contrast, almost all AChR aggregates are associated with dystroglycan immunoreactivity, and monoclonal antibody (mAb) IIH6 against $\alpha$-dystroglycan ( $\alpha$-DG), a LN and agrin receptor, causes a concentration-dependent inhibition of LN-induced aggregation. Moreover, S27 cells, which lack a functional $\alpha$-DG, and two C2-derived cell lines expressing antisense DG mRNA fail to aggregate AChRs in response to $L N$. Finally, LN-induced AChR aggregation does not involve the phosphorylation of the muscle-specific tyrosine kinase receptor (MuSK) or the AChR $\beta$ subunit. We hypothesize that the interaction of LN with $\alpha$-DG contributes to the growth and/or stabilization of AChR microaggregates into macroaggregates at the developing NMJ via a MuSK-independent mechanism.

Key words: laminin; $\alpha$-dystroglycan; acetylcholine receptor aggregation; neuromuscular synapse; agrin; MuSK
At the adult neuromuscular junction (NMJ), sites of transmitter release are aligned precisely opposite postjunctional folds in the muscle membrane. At the crests of the folds, acetylcholine receptors (AChRs) are packed at a density of $\sim 10,000 / \mu \mathrm{m}^{2}$ (Fertuck and Salpeter, 1974), whereas in adjacent regions of the membrane, the receptor density is $\sim 1000$-fold less. Before innervation, AChRs are diffusely distributed, but within hours of the first contact of the nerve terminal and muscle fiber, AChRs in the postsynaptic membrane begin to aggregate (Bevan and Steinbach, 1977). These early synapses are composed of loose assemblies of small receptor patches (Anderson and Cohen, 1977; Olek et al., 1986) that subsequently coalesce into more tightly organized receptor "plaques" that further increase in size and density until

\footnotetext{
Received Sept. 12, 1997; revised Nov. 17, 1997; accepted Nov. 26, 1997.

This work was supported by grants to S.C. from the Medical Research Council of Canada (MA 9000 and MA 10182), the National Centres of Excellence, and the Muscular Dystrophy Association (USA) and to S.C.F from the National Institutes of Health. F.M. and C.J. were supported by studentships from the National Centres of Excellence. During part of this research, S.H.G. was supported by a postdoctora fellowship from the Medical Research Council of Canada. We thank Drs. Steven Roberds and Kevin Campbell (University of Iowa) for supplying antibodies to $\alpha$-DG, Dr. John Lindstrom (University of Pennsylvania) for supplying monoclonal antibody to the AChR $\beta$ subunit, and Dr. James E. Faber for the use of his image capture apparatus. Neural agrin was a gift from Drs. James Campanelli and Richard Scheller (Stanford University) and Dr. Michael Ferns (McGill University).

F.M. and S.H.G. contributed equally to this study.

Correspondence should be addressed to Dr. Salvatore Carbonetto, Montreal General Hospital Research Institute, 1650 Cedar Avenue, Montreal, Quebec H3G 1A4, Canada.

Copyright (C) 1998 Society for Neuroscience $\quad 0270-6474 / 98 / 181250-11 \$ 05.00 / 0$
}

they attain the proportions found in the adult postsynaptic membrane (Steinbach, 1981).

Agrin released from the nerve terminal has been shown to activate the muscle-specific tyrosine kinase receptor MuSK leading to the aggregation of AChRs in the postsynaptic membrane (Valenzuela et al., 1995; DeChiara et al., 1996; Glass et al., 1996). Several studies have shown that agrin, in addition to triggering the aggregation of AChRs, also induces the aggregation of other synaptic proteins including laminin (LN), the heparan sulfate proteoglycan perlecan, acetylcholinesterase, muscle agrin, rapsyn, $\alpha$-actinin, filamin, vinculin, and $\alpha$ - and $\beta$-dystroglycan $(\beta$-DG) (Daniels et al., 1984; Wallace, 1989; Nitkin and Rothschild, 1990; Shadiack and Nitkin, 1991; Lieth et al., 1992; Cohen et al., 1995). Furthermore, in skeletal muscle from MuSK knockout mice, there is a complete failure in synapse formation, indicating that as for AChRs, agrin-induced aggregation of extracellular matrix (ECM), membrane, and cytoskeletal proteins requires the activation of MuSK. Therefore, agrin activation of MuSK initiates the creation of a separate compartment within the muscle fiber containing a specialized synaptic basal lamina (BL), as well as membrane and cytoskeletal proteins.

Several previous results indicate that LN may assist agrin in the formation and consolidation of postjunctional AChR aggregates. For example, LN is concentrated at agrin-induced AChR aggregates in culture, and isoforms of $\mathrm{LN}$ containing the $\beta 2$ chain are restricted to the NMJ (Hunter et al., 1989). Furthermore, LN has been reported to induce AChR aggregation on cultured myotubes and to enhance the aggregating activity of a neuroblastoma $\times$ 
glioma hybrid cell-conditioned medium with agrin-like activity (Vogel et al., 1983). Recently, Denzer et al. (1997) reported that agrin isoforms containing a 15 amino acid N-terminal insertion bind with different affinities to $\mathrm{LN}$, showing a preference for heterotrimers containing the synapse-specific $\beta 2 \mathrm{LN}$ chain. AChR aggregates induced by this agrin splice variant are considerably smaller than are those induced by $\mathrm{C}$-terminal fragments of agrin, suggesting that the interaction of agrin with $\mathrm{LN}$ can modulate the size of AChR aggregates.

Several LN receptors have been shown to be expressed and developmentally regulated in skeletal muscle and the $\mathrm{C} 2$ mouse muscle cell line. These include members of the integrin family of heterodimeric ECM receptors (Song et al., 1992; Collo et al., 1993; Belkin et al., 1996) as well as the dual LN and agrin receptor $\alpha$-dystroglycan ( $\alpha$-DG), which is an extracellular peripheral membrane protein and a member of the dystrophin/utrophinassociated protein complex (Smalheiser and Schwartz, 1987; Douville et al., 1988; Ervasti and Campbell, 1991, 1993; IbraghimovBeskrovnaya et al., 1992; Matsumura et al., 1992; Gee et al., 1993). Most integrins that bind LN contain the $\beta 1$ subunit that is found at NMJs (Bozyczko et al., 1989; Belkin et al., 1996) and at agrin- and nerve-induced AChR aggregates in cultured myotubes (Bozyczko et al., 1989; Anderson and Qiao Shi, 1996). LN also binds with high affinity to $\alpha-\mathrm{DG}$, and this interaction is thought to play a role in maintaining the structural integrity of the sarcolemma (Henry and Campbell, 1996). $\alpha$-DG is concentrated at the NMJ in vivo (Matsumura et al., 1992) and at AChR aggregates in cultured myotubes (Cohen et al., 1995) and has been implicated in AChR aggregation (Campanelli et al., 1994; Gee et al., 1994, Cohen et al., 1995; but see Sugiyama et al., 1994). In the present study, we sought to determine the role of $\mathrm{LN}$ in agrin-induced AChR aggregation and to identify the receptor involved. We find that agrin-induced aggregation of AChRs is accompanied by a recruitment of $\mathrm{LN}$ at these aggregates and that exogenous $\mathrm{LN}$ alone induces the aggregation of AChRs on $\mathrm{C} 2$ myotubes in addition to potentiating the aggregating activity of agrin. We further show that LN-mediated AChR aggregation does not involve the phosphorylation of MuSK or the AChR $\beta$ subunit. Finally, we used three mutant cell lines derived from the $\mathrm{C} 2$ cell line that express reduced levels of $\alpha$-DG to demonstrate that this receptor is responsible for the observed effects of $\mathrm{LN}$ on $\mathrm{AChR}$ aggregation. Our results suggest a role for $\mathrm{LN}$ and $\alpha$-DG in the growth and/or stabilization of AChRs into compact aggregates during synapse formation at the NMJ.

\section{MATERIALS AND METHODS}

Materials. LN was purified from Engelbreth-Holm-Schwarm (EHS) tumor by the method of Timpl et al. (1982). Coomassie blue- and silver-stained gels revealed only two bands at $\sim 215 \mathrm{kDa}(\beta / \gamma$ chains) and $400 \mathrm{kDa}$ ( $\alpha$ chain) that did not cross-react with a monoclonal antibody to the LN $\alpha 2$. Polyclonal anti-LN antiserum was produced by immunizing rabbits with EHS tumor LN. This antiserum has been characterized previously (Morissette and Carbonetto, 1995) and recognizes all three subunits of $\mathrm{LN} 1(\alpha 1, \beta 1$, and $\gamma 1)$ with a very faint band at $150 \mathrm{kDa}$ corresponding to entactin. There is no cross-reactivity with agrin (F. Montanaro and S. Carbonetto, unpublished observations) or LN $\alpha 2$ chain (Morissette and Carbonetto, 1995). Anti-LN antiserum was purified by chromatography on Affi-Gel Blue (Bio-Rad, Hercules, CA) according to the manufacturer's instructions and was subsequently dialyzed into PBS, pH 7.2. Recombinant rat $\operatorname{agrin}_{(12,4,8)}$ was purified from the conditioned medium of COS cells expressing a truncated C-terminal fragment (amino acids 1145-1940) (Ferns et al., 1993). Monoclonal antibody (mAb) IIH6 ascites fluid was prepared as described previously (Ervasti and Campbell, 1991). Monoclonal antibodies to $\beta$-DG and to the core protein of mouse perlecan were purchased from Novo Castra
Laboratories (Newcastle upon Tyne, UK) and Chemicon (Temecula, $\mathrm{CA}$ ), respectively. Monoclonal antibody $3 \mathrm{~A} 3$ is directed against the rat integrin $\alpha 1$ subunit and was prepared as described previously (Turner et al., 1989). The polyclonal antiserum to the integrin $\beta 1$ subunit was generated by immunizing rabbits with purified native rat integrin $\beta 1$ subunit (Tawil et al., 1990). The polyclonal antiserum to mouse collagen IV was purchased from Chemicon. Polyclonal anti-MuSK antiserum was prepared by immunizing rabbits with a synthetic peptide corresponding to the C-terminal 20 amino acids of the rat MuSK protein (Glass et al., 1996).

Cell culture. C2 and S27 myotubes were cultured as described previously (Gee et al., 1994) on collagen-coated 18-mm-round glass coverslips in scored wells on $100 \mathrm{~mm}$ Petri plates. For experiments involving the DG-antisense cell lines, 11F, 11E, and control C2 cells were cultured on Falcon tissue culture plastic dishes coated with $0.15 \%$ gelatin. Cells were kept in growth medium (DMEM high glucose plus 10\% fetal bovine serum; plus $70 \mu \mathrm{g} / \mathrm{ml} \mathrm{G}-418$ for $11 \mathrm{~F}$ and $11 \mathrm{E}$ cells only) until confluent. Cultures were then switched to fusion medium (DMEM high glucose plus $1 \%$ horse serum) and allowed to differentiate for an additional $4 \mathrm{~d}$. All cells were treated with $\mathrm{LN}$, agrin, or anti-LN IgG on the third day of fusion.

Immunofluorescence microscopy. To visualize surface AChRs, we incubated myotubes with BODIPY- or rhodamine-conjugated $\alpha$-bungarotoxin (Molecular Probes, Eugene, OR) for $30 \mathrm{~min}$ at room temperature. Myotubes were fixed with $2 \%$ paraformaldehyde in $0.1 \mathrm{M}$ phosphate buffer, $\mathrm{pH}$ 7.2, for $20 \mathrm{~min}$ and rinsed three times with PBS. For antibody staining, the myotubes were fixed as above and then blocked for $1 \mathrm{hr}$ with PBS plus $1 \%$ horse serum. Cells were incubated with primary antibody in blocking buffer for $1 \mathrm{hr}$ and then with the appropriate biotin-conjugated secondary antibody for an additional hour, followed by fluorescein-conjugated streptavidin for $20 \mathrm{~min}$.

Quantification of AChR colocalization and number. All quantifications were performed by visual inspection of a minimum of 10 random fields using a $40 \times$ objective. For colocalization studies, AChR aggregates were scored as partially overlapping with the antigen of interest if at least a quarter of their surface colocalized with the antigen. AChR aggregates were scored as completely overlapping if the antigen immunoreactivity was coextensive with $\alpha$-bungarotoxin staining in both size and shape. Determination of the number of AChR aggregates per myotube segment was performed as described previously (Gee et al., 1994). A myotube segment corresponds to $5.6 \times 10^{3} \mu \mathrm{m}^{2}$.

Quantification of AChR number, size, and intensity for Table 2. Thirtyfive millimeter negatives were scanned into Adobe Photoshop for Windows (version 2.5.1) using an Agfa Arcus II scanner and FotoLook (version 2.05) with TWAIN acquisition. Brightness and contrast were adjusted to -25 and +25 , respectively. Files were saved in TIFF format (for MacIntosh) and imported into NIH Image (version 1.59b). Images were processed with Invert Filter; then the background was subtracted using the two-dimensional rolling ball method (radius, 5-15). Background-subtracted images were analyzed for particle size and mean pixel intensity after thresholding the image. The mean pixel intensity is the average gray value for all of the pixels in an aggregate. The possible values for each pixel range from 0 (white) to 255 (black). Thresholded images were carefully compared with their unprocessed counterparts to ensure that AChR aggregate size and number were accurate. Measurements were imported into Excel (version 5.0; Microsoft) and SigmaPlot (version 5.0; Jandel Scientific, Corte Madera, CA) for analysis. AChR aggregates of $<1.0 \mu \mathrm{m}^{2}$ were not included because image thresholding of low intensity or out-of-focus aggregates accounted for the majority of particles of this size.

Immunoprecipitation. For immunoprecipitations, cultures of $100 \mathrm{~mm}$ dishes of $\mathrm{C} 2$ myotubes were treated with agrin or $\mathrm{LN}$ for $15 \mathrm{~min}$, rinsed with $\mathrm{Ca}^{2+}$ - and $\mathrm{Mg}^{2+}$-free PBS containing $1 \mathrm{~mm}$ sodium vanadate, then harvested by scraping, and pelleted. Cell pellets were extracted for 15 min on ice with $25 \mathrm{~mm}$ Tris-glycine, $\mathrm{pH} 7.5,150 \mathrm{~mm} \mathrm{NaCl}, 5 \mathrm{~mm}$ EDTA, $1 \%$ Triton $\mathrm{X}-100,1 \mathrm{~mm}$ sodium vanadate, $50 \mathrm{~mm}$ sodium fluoride, $1 \mu \mathrm{M}$ aprotinin, $1 \mu \mathrm{M}$ leupeptin, $1 \mu \mathrm{M}$ pepstatin A, $1 \mathrm{~mm}$ benzamidine, $1 \mathrm{~mm}$ iodoacetamide, and $1 \mathrm{~mm}$ PMSF. Insoluble material was pelleted by centrif ugation at $15,000 \times g$ for $10 \mathrm{~min}$ at $4^{\circ} \mathrm{C}$. Extracts of $\mathrm{C} 2$ myotubes were incubated with anti-MuSK antisera for $1 \mathrm{hr}$ at $4^{\circ} \mathrm{C}$ with agitation; then immune complexes were precipitated by addition of protein $\mathrm{G}-$ Sepharose beads. The beads were pelleted at $1500 \times g$ and were washed three times with $50 \mathrm{~mm}$ Tris- $\mathrm{HCl}, \mathrm{pH} 8.0,0.5 \mathrm{M} \mathrm{NaCl}, 50 \mathrm{~mm}$ sodium vanadate, and $1 \%$ Triton $\mathrm{X}-100$. Bound proteins were eluted with $30 \mu \mathrm{l}$ of reducing SDS-PAGE sample buffer. To isolate AChRs, we 
Table 1. Overlap of LN and other proteins with AChR aggregates

\begin{tabular}{llllll} 
& \multicolumn{2}{l}{ Spontaneous } & & Agrin-induced & \\
\cline { 2 - 3 } AChR Aggregates & $100 \%$ Overlap & $25-100 \%$ Overlap & & $100 \%$ Overlap & $25-100 \%$ Overlap \\
\hline LN & $38 \%(n=489)$ & $81 \%(n=139)$ & & $83 \%(n=129)$ & $95 \%(n=129)$ \\
Perlecan & $46 \%(n=91)$ & $66 \%(n=91)$ & & $95 \%(n=156)$ & $99 \%(n=156)$ \\
Collagen IV & N.D. & $56 \%(n=247)$ & & N.D. & $68 \%(n=285)$ \\
Integrin $\beta 1$ subunit & $0 \%(n=117)$ & $23 \%(n=117)$ & & $2 \%(n=115)$ & $12 \%(n=115)$ \\
\hline
\end{tabular}

Untreated C2 myotubes (spontaneous) and C2 myotubes that had been treated overnight with 200 pM agrin (agrin-induced) were double labeled for AChR aggregates using rhodamine-conjugated $\alpha$-bungarotoxin and for the proteins indicated using indirect immunofluorescence with specific antibodies. The extent of overlap of these proteins with AChR aggregates was quantified by visual inspection. Overlap was considered complete if $100 \%$ of an aggregate was coextensive with immunoreactivity for the protein and partial if $<100 \%$ but $>25 \%$ was coextensive. Aggregates with $<25 \%$ overlap with the protein were considered nonoverlapping. Data indicate the percentage of AChR aggregates that scored positive for overlap. The total number of AChR aggregates visualized is given in parenthesis. N.D., Not determined.

incubated C2 myotube cultures with $0.1 \mu \mathrm{g} / \mathrm{ml}$ biotin-conjugated $\alpha$-bungarotoxin for $1 \mathrm{hr}$ at $25^{\circ} \mathrm{C}$, harvested and extracted the cells as described above, then added $100 \mu \mathrm{l}$ of streptavidin-Sepharose beads, and incubated the mixture at $4^{\circ} \mathrm{C}$ for $1 \mathrm{hr}$. The beads were washed and prepared for SDS-PAGE as described above.

Western blot analysis. Samples were electrophoretically separated on $8 \%$ SDS-PAGE gels and transferred onto nitrocellulose membranes. The proteins were probed with a monoclonal anti-phosphotyrosine antibody (mAb 4G10) (Upstate Biotechnology, Saranac Lake, NY) in buffer containing 5\% BSA, $10 \mathrm{~mm}$ Tris- $\mathrm{HCl}, \mathrm{pH} 7.4,0.15 \mathrm{~m} \mathrm{NaCl}, 0.5 \%$ Nonidet P-40, and $0.1 \%$ Tween 20 . The blots were then incubated with a horseradish peroxidase-conjugated anti-mouse Ig secondary antibody (Amersham, Arlington Heights, IL). Bound antibody was visualized by chemiluminescence (ECL) (Amersham).

\section{RESULTS}

\section{LN colocalizes with AChR aggregates in $\mathrm{C} 2$ cells}

Previous studies have shown that LN colocalizes with AChR aggregates in cultured myotubes (Vogel et al., 1983; Bayne et al., 1984; Olwin and Hall, 1985; Nitkin and Rothschild, 1990; Gordon et al., 1993) and that it is concentrated at synapses in vivo (Sanes et al., 1990). In addition, agrin treatment of cultured chick myotubes was also shown to promote a rearrangement of LN on the cell surface (Nitkin and Rothschild, 1990). We therefore sought to confirm and quantify the presence of $\mathrm{LN}$ at both spontaneous and agrin-induced AChR aggregates in C2 myotubes. Cultures were double labeled with a polyclonal antiserum to $\mathrm{LN}$ and with rhodamine-conjugated $\alpha$-bungarotoxin to visualize AChRs. LN was found to be concentrated at most spontaneous and agrininduced AChR aggregates (Table 1, Fig. 1). In agreement with a previous report (Gordon et al., 1993), LN immunoreactivity was also found in a punctate pattern on the myotube surface and in a few patches devoid of AChRs (Fig. 1). The amount of overlap of LN with AChR aggregates was categorized as partial or complete. Overlap was considered partial when $\geq 25 \%$ of the surface of the AChR aggregate was associated with LN immunoreactivity and complete when the two proteins were coextensive. In untreated $\mathrm{C} 2$ myotubes, $\sim 81 \%$ of spontaneous AChR aggregates overlapped partially with LN, and in $38 \%$, the overlap was complete (Table 1). Overnight treatment of C2 myotubes with $200 \mathrm{pm}$ of a recombinant neural agrin fragment $\left[\mathrm{C}-\operatorname{Agrin}_{(4,8)}\right.$, hereafter referred to as agrin] increased the overlap of $\mathrm{LN}$ in almost all AChR aggregates, with a more than twofold increase in the number of AChR aggregates that overlap completely with LN (Table 1). To determine the specificity of this recruitment of LN to AChR aggregates in $\mathrm{C} 2$ cells, we mapped the distribution of other proteins found concentrated at the neuromuscular junction in vivo (Sanes et al., 1990; Belkin et al., 1996) and at spontaneous and agrin-induced AChR aggregates: collagen IV, the heparan sulfate proteoglycan perlecan, and the integrin $\beta 1$ subunit. We found that only perlecan shows a high degree of overlap with spontaneous AChR aggregates, and this overlap is increased by agrin treatment. In contrast, collagen IV showed a poor colocalization with spontaneous AChR aggregates and was often concentrated in large patches devoid of AChRs on the cell surface (Fig. 1, Table 1). Similar poor colocalization was found with antisera for fibronectin (Montanaro and Carbonetto, unpublished observations). Agrin did not greatly increase localization of collagen IV at AChR aggregates, nor did it seem to alter its distribution on the cell surface. Only a subset of collagen IV chains have been shown to be specifically concentrated at synapses (Sanes et al., 1990), and we cannot exclude the possibility that the low level of colocalization of collagen IV with AChR aggregates is attributable to the inability of our antibody to recognize the synapse-specific collagen IV chains. However, our data indicate that agrin does not cause a reorganization of all $\mathrm{BL}$ components but selectively recruits $\mathrm{LN}$ and perlecan to $\mathrm{AChR}$ aggregates in C2 myotubes. Similar results have been reported with cultures of primary myotubes (Nitkin and Rothschild, 1990).

Two classes of LN receptors are expressed in skeletal muscle and C2 cells, integrins and $\alpha$-DG (Collo et al., 1993; Ervasti and Campbell, 1993; Song et al., 1992; Gee et al., 1994; Belkin et al., 1996). Integrins comprise a family of cell adhesion molecules composed of heterodimers of $\alpha$ and $\beta$ subunits (for review, see Hynes, 1992). LN-binding integrins found in skeletal muscle contain the $\beta 1$ subunit, and their expression is developmentally regulated in both muscle and C2 cells (Collo et al., 1993; Belkin et al., 1996). Antibodies to the $\beta 1$ subunit label NMJs (Belkin et al., 1996) as well as AChR aggregates in Xenopus myocyte and chick myotube cultures (Bozyczko et al., 1987; Anderson et al., 1996). In our studies, we used an antiserum directed against the extracellular domain of the integrin $\beta 1$ subunit that should recognize all cytoplasmic splice variants expressed in these cells. We found a very poor correlation with both spontaneous and agrininduced AChR aggregates in C2 cells (Fig. 1, Table 1). Agrin did not seem to change the distribution of this integrin subunit that remained concentrated in large plaques on the cell surface (Fig. 1 , open arrow), its distribution resembling more that of collagen IV than that of LN. By contrast, both $\alpha$ - (data not shown) and $\beta$-DG (Fig. 1) are concentrated at and overlap completely with essentially all AChR aggregates (>95\%). Taken together, our results show that agrin specifically recruits $\mathrm{LN}$ and perlecan at AChR aggregates in $\mathrm{C} 2$ cells. Furthermore, the low level of 

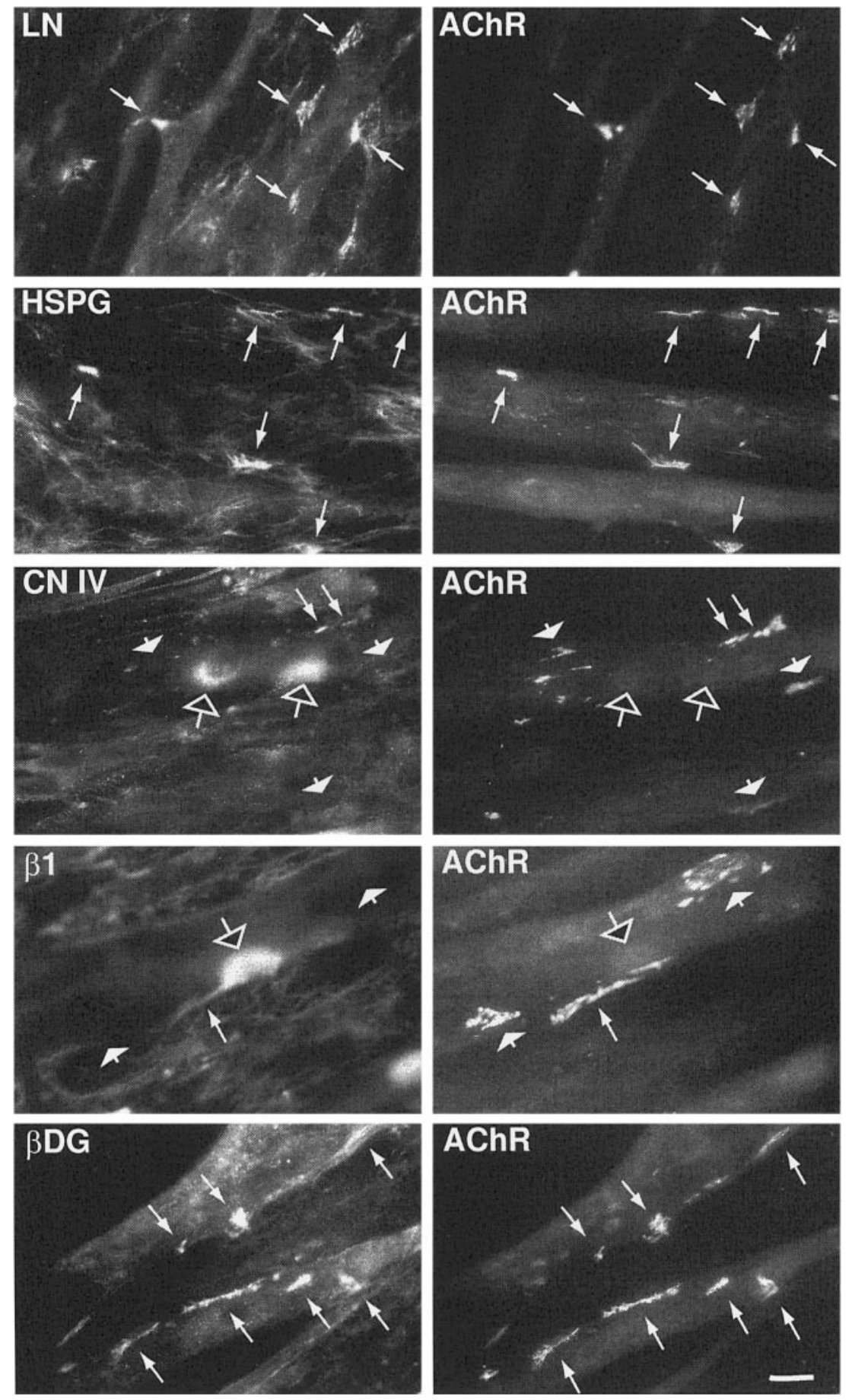

Figure 1. Colocalization of some synaptic proteins with agrin-induced AChR aggregates. C2 myotubes were incubated with $100 \mathrm{pm}$ agrin for $18 \mathrm{hr}$ and then double labeled with rhodamine-conjugated $\alpha$-bungarotoxin and with antibodies specific for $L N$, perlecan (HSPG), collagen IV $(C N I V)$, integrin $\beta 1$ subunit $(\beta 1)$, or $\beta-D G$. Both $\mathrm{LN}$ and perlecan are distributed diffusely on the surface of the myotubes and in the surrounding matrix but are highly concentrated at and fully coextensive with most AChR aggregates (long arrows). Collagen IV and the integrin $\beta 1$ subunit were present in diffuse patches devoid of AChRs (open arrows) and were found to colocalize with only a few AChR aggregates (long arrows). The vast majority of AChR aggregates had no detectable collagen IV or integrin $\beta 1$ immunoreactivity associated with them (short arrows). $\beta$-DG immunoreactivity was present over the entire myotube and highly concentrated at both large and small AChR aggregates (long arrows). Scale bar, $20 \mu \mathrm{m}$. colocalization of the integrin $\beta 1$ subunit with AChR aggregates in $\mathrm{C} 2$ cells suggests that this receptor is unlikely to be responsible for the recruitment of $\mathrm{LN}$ into aggregates. Rather, $\alpha$-DG, which is consistently concentrated at both spontaneous and agrininduced AChR aggregates, seems a better candidate.

\section{LN induces large AChR aggregates}

The possibility that $\mathrm{LN}$ is involved in later stages of $\mathrm{AChR}$ aggregate formation, such as the maturation of aggregates, was suggested by the observation that agrin-induced reorganization of the ECM lags behind AChR aggregation (Nitkin and Rothschild, 1990). To test this possibility, we treated C2 myotubes with either agrin or LN, measured the number, size, and density of AChR aggregates, and compared these values with those of control cultures. In the absence of added agrin or LN, C2 myotubes had an average of $9 \pm 1$ spontaneous aggregates per field with a mean size of $16.4 \pm 1.8 \mu \mathrm{m}^{2}$ ( $n=10$ fields; Table 2, Fig. $2 A, E)$. Spontaneous aggregates had a mean pixel intensity of $133 \pm 6$ (out of a possible 255), reflecting the density of AChRs within an aggregate. Treatment of C2 myotubes with 200 pM agrin induced a more than threefold increase in the number of $\mathrm{AChR}$ aggregates compared with control cultures (Table 2, Fig. 2B,F); however this increase in number was accompanied by a twofold decrease in size and a 1.4-fold decrease in apparent density. In 
Table 2. Quantitation of AChR aggregate number, size, and intensity in C2 myotubes

\begin{tabular}{lcrrr} 
& & & \multicolumn{3}{c}{$\begin{array}{l}\text { Mean average } \\
\text { intensity }(\text { min } \\
=0, \text { max }=\end{array}$} \\
Treatment & $\begin{array}{l}\text { Mean number } \\
\text { per field }\end{array}$ & $\begin{array}{l}\text { Mean area } \\
\left(\mu \mathrm{m}^{2}\right)\end{array}$ & $\begin{array}{l}\text { 255) } \\
\text { area } \\
\left(\mu \mathrm{m}^{2}\right)\end{array}$ \\
\hline Control & $9 \pm 1(n=11)$ & $16.4 \pm 1.8$ & $133 \pm 6$ & 150 \\
Agrin $(200 \mathrm{pM})$ & $34 \pm 4(n=13)$ & $7.5 \pm 0.9$ & $95 \pm 9$ & 306 \\
LN $(60 \mathrm{nM})$ & $21 \pm 2(n=10)$ & $17.4 \pm 1.6$ & $163 \pm 7$ & 356 \\
Agrin $(200 \mathrm{pM})$ & $101 \pm 14(n=10)$ & $3.8 \pm 0.2$ & $73 \pm 6$ & 385 \\
$\quad+$ anti-LN IgG & & & & \\
$\quad(100 \mu \mathrm{g} / \mathrm{ml})$ & & & &
\end{tabular}

$\overline{\text { Cultures were treated overnight with the indicated concentrations of neural agrin }}$ (Ferns et al., 1993), LN, and/or purified anti-laminin IgG. AChR aggregate number, size, and intensity were quantitated as described in Materials and Methods. The means for the indicated number of fields $(n)$ containing at least one AChR aggregate are shown \pm SEM. Total area refers to the area of the myotube occupied by AChR aggregates and is the product of the mean number of aggregates per field and the mean area of each aggregate.

spite of the small size of the AChR aggregates, their large number resulted in an increase from 150 to $306 \mu \mathrm{m}^{2}$ in the total area per field occupied by AChR aggregates (Table 2).

Treatment of C2 cells with $60 \mathrm{~nm} \mathrm{LN}$ resulted in an approximately twofold increase in the number of $\mathrm{AChR}$ aggregates compared with control cultures (Table 2, Fig. 2C, $G$ ). The average size of $\mathrm{LN}$-induced $\mathrm{AChR}$ aggregates was more than double that of agrin-induced aggregates, resulting in a greater total area occupied by AChR aggregates (Table 2). Furthermore, the AChR density of $\mathrm{LN}$-induced aggregates was higher than that of either spontaneous or agrin-induced aggregates. Thus LN alone induces the formation of large, dense AChR aggregates. To explore the function of $\mathrm{LN}$ in agrin-induced AChR aggregation, we incubated C2 myotubes with 200 pM agrin in the presence of 100 $\mu \mathrm{g} / \mathrm{ml}$ anti-LN antiserum. This antiserum was raised against purified EHS LN and does not cross-react with the recombinant agrin used in these experiments. As a control for nonspecific antibody effects, an equal concentration of a polyclonal antibody to collagen IV was added to identical cultures of $\mathrm{C} 2$ myotubes, and no obvious effect on the size or number of AChR aggregates was observed (data not shown). Only in cultures treated with the anti-LN antiserum was there a dramatic increase in the number of AChR aggregates (Table 2, Fig. 2D,H). These AChR aggregates were half the size of the aggregates observed in cultures treated with agrin alone and had a slightly lower AChR density. A large proportion $(>80 \%)$ of the myotubes cultured in the presence of anti-LN antiserum showed only microaggregates on their surface (see Fig. 2D,H). These microaggregate-rich myotubes were sometimes seen in control and agrin-treated cultures. However they were absent in cultures treated with LN alone or with LN and agrin together. Because the total area covered by AChR aggregates in the presence of the anti-LN antiserum is comparable with that for agrin alone, this antiserum did not seem to completely disperse aggregates into individual AChRs. From these results, we hypothesize that agrin increases the number of AChR microaggregates, while recruiting $\mathrm{LN}$ to promote the formation of large, high density aggregates from microaggregates or possibly to inhibit the breakup of larger aggregates into microaggregates.

\section{LN-induced AChR aggregation is mediated by $\alpha$-DG}

Our immunocytochemical data on integrin and $\alpha$-DG localization favored the latter as a receptor mediating the effects of $\mathrm{LN}$ on AChR aggregation. To test this further, we quantified the induction of AChR aggregates by $\mathrm{LN}$ on $\mathrm{C} 2$ myotubes and on a genetic variant of the $\mathrm{C} 2$ muscle cell line S27, which is deficient in the synthesis of glycosaminoglycans (Gordon and Hall, 1989). We and others (Gee et al., 1994; Sugiyama et al., 1994) have shown previously that S27 cells have reduced expression of $\alpha$-DG as well as reduced binding of the residual $\alpha$-DG to agrin and LN. These cells also have no spontaneous AChR aggregates and respond poorly to agrin (Gordon et al., 1993). In C2 cells incubated for 18 hr with various concentrations of $\mathrm{LN}$, there was a maximal increase (twofold) in AChR aggregates at $60 \mathrm{~nm} \mathrm{LN} \mathrm{(Fig.} \mathrm{3).} \mathrm{In}$ contrast, LN failed to cause aggregation of AChRs on S27 myotubes, even at concentrations as high as $120 \mathrm{~nm}$. Like spontaneous and agrin-induced aggregation, LN-induced aggregation seems to require a functional $\alpha$-DG and the normal synthesis of glycosaminoglycans.

Because $\alpha$-DG is not the only protein affected by the mutation in S27 cells, we assessed the involvement of $\alpha$-DG in LN-induced AChR aggregation with mAb IIH6. mAb IIH6 recognizes a unique carbohydrate epitope on $\alpha$-DG and inhibits binding of both $\mathrm{LN}$ and agrin to $\alpha$-DG on blots (Gee et al., 1994; Sugiyama et al., 1994). A control monoclonal antibody to the rat integrin $\alpha 1$ subunit, mAb 3A3, had no effect on $\mathrm{LN}$ induced aggregation (data not shown). Treatment of $\mathrm{C} 2$ cells with $\mathrm{LN}$ in the presence of increasing concentrations of $\mathrm{mAb}$ IIH6 resulted in a dose-dependent inhibition of $\mathrm{LN}$-induced AChR aggregation (Fig. 4). A significant effect was observed at mAb IIH6 concentrations as low as 1:200 dilution. Higher concentrations of mAb IIH6 decreased the number of AChR aggregates to that occurring spontaneously in $\mathrm{C} 2$ cells. No obvious change in the morphology of the remaining aggregates was observed. Although others (Campanelli et al., 1994; Cohen et al., 1995; but see Sugiyama et al., 1994) have reported effects of mAb IIH6 similar to those we saw with the anti-LN antiserum, in our hands these antibodies had different effects possibly because the functions of $\alpha-\mathrm{DG}$ in AChR aggregation are not limited to those of $\mathrm{LN}$.

To confirm that $\alpha$-DG is involved in $\mathrm{LN}$-induced AChR aggregation, we generated $\mathrm{C} 2$ clonal cell lines that stably express antisense cDNA to DG. Two such cell lines, $11 \mathrm{~F}$ and $11 \mathrm{E}$, show reductions of 50 and $80 \%$, respectively, in $\alpha-\mathrm{DG}$ expression relative to $\mathrm{C} 2$ cells. These cells fuse to form myotubes and express normal levels of other proteins including adhalin, LN, and AChRs (M. Lindenbaum, F. Montanaro, and S. Carbonetto, unpublished observations). C2, 11F, and $11 \mathrm{E}$ myotubes were incubated in the presence of $60 \mathrm{~nm} \mathrm{LN}$ for 18 hr and then assayed for AChR aggregation. Figure 5 shows that $\mathrm{LN}$ induced a 1.8-2-fold increase in the number of $\mathrm{AChR}$ aggregates in $\mathrm{C} 2$ cells regardless of the level of spontaneous $\mathrm{AChR}$ aggregates. In contrast, there was little change in the number of AChR aggregates in $11 \mathrm{~F}$ and $11 \mathrm{E}$ cells treated with LN (Fig. 5). In other experiments (see below; C. Jacobson, F. Montanaro, M. Lindenbaum, S. Carbonetto, and M. Ferns, unpublished observations), we have shown that $11 \mathrm{~F}$ and $11 \mathrm{E}$ cells produce a significant, although reduced, response to agrin when compared with $\mathrm{C} 2$ cells, indicating that they are not inherently incapable of responding to agents known to induce AChR aggregation. Taken together, our results suggest that $\alpha-\mathrm{DG}$ is required for $\mathrm{LN}$-induced $\mathrm{AChR}$ aggregation in $\mathrm{C} 2$ cells. 

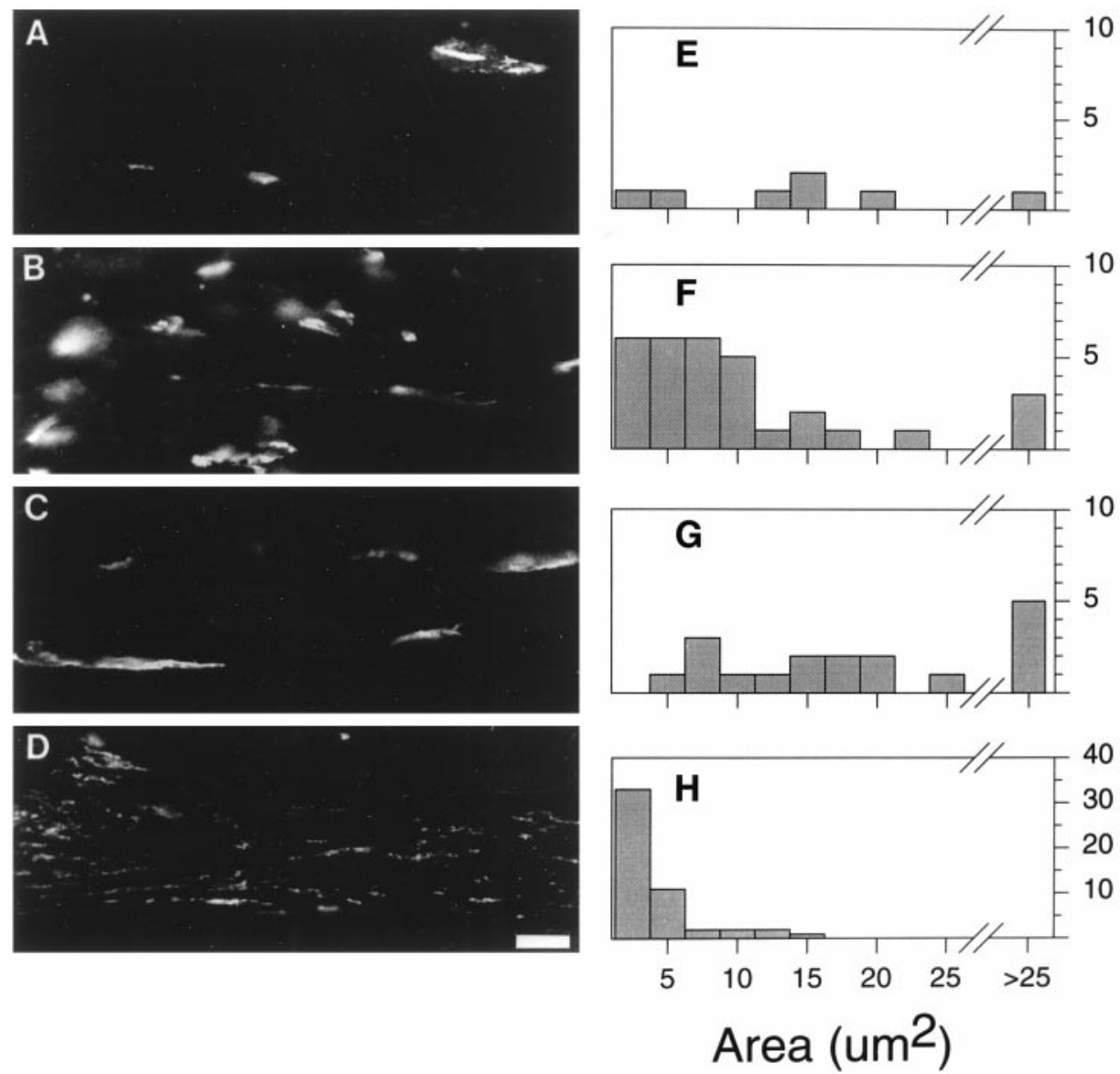

10

10

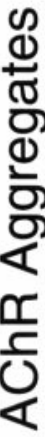

Figure 2. LN affects the size of AChR aggregates. Cultures of $\mathrm{C} 2$ myotubes were incubated overnight in fusion medium alone $(A, E)$ or in fusion medium containing $200 \mathrm{pm}$ agrin $(B, F), 60 \mathrm{~nm}$ $\mathrm{LN}(C, G)$, or $200 \mathrm{pm}$ agrin plus $100 \mu \mathrm{g} / \mathrm{ml}$ anti-LN $\operatorname{IgG}(D, H) . A-D$, Representative fields of $\mathrm{C} 2$ myotubes labeled with rhodamine-conjugated $\alpha$-bungarotoxin for each treatment. $E-H$, Representative frequency distribution histograms of AChR aggregate areas. Note that the scale of the $y$-axis of $H$ (agrin + anti-LN) is four times that of $E-G$. The addition of $\mathrm{LN}$ to $\mathrm{C} 2$ myotube cultures results in an increase in the area of AChR aggregates, whereas the addition of anti-LN IgG results in an dramatic increase in the number of small AChR aggregates $(<5$ $\mu \mathrm{m}^{2}$ ). Scale bar, $10 \mu \mathrm{m}$.

\section{LN interaction with $\alpha$-DG enhances agrin-induced AChR aggregation}

Vogel et al. (1983) reported that LN can enhance the AChR aggregating activity of a factor in neuroblastoma-conditioned medium. Because agrin is produced by a variety of neural cells, we tested whether recombinant agrin might also act cooperatively with $\mathrm{LN}$ in this regard and further whether this was mediated by $\alpha$-DG. To optimize the sensitivity of this assay, we used a subthreshold concentration of LN (12 nM) that alone did not cause any increase in the number of $\mathrm{AChR}$ aggregates in $\mathrm{C} 2,11 \mathrm{~F}$, or $11 \mathrm{E}$ cells (Fig. 6). Addition of agrin alone to C2, IIF, and IIE cultures caused a significant increase in the number of $\mathrm{AChR}$ aggregates. This increase was enhanced significantly by simultaneous treatment with agrin and LN (12 nM) in C2 and to a lesser extent in IIF cells, but there was no effect in IIE cells. These results show that $\mathrm{LN}$ can potentiate the activity of agrin and that $\alpha$-DG is involved in this process.

\section{LN does not induce the phosphorylation of MuSK or the AChR $\beta$ subunit}

Neural agrin induces a rapid, but transient, phosphorylation of the receptor tyrosine kinase MuSK that subsequently leads to the phosphorylation of the AChR $\beta$ subunit (Wallace et al., 1991; Qu and Huganir, 1994; DeChiara et al., 1996; Ferns et al., 1996; Glass et al., 1996). We therefore sought to determine whether LNinduced AChR aggregation is similarly dependent on the phosphorylation of MuSK and leads to the phosphorylation of the AChR $\beta$ subunit. AChRs were isolated using $\alpha$-bungarotoxin conjugated to Sepharose beads, and MuSK was immunoprecipitated. Isolates were then analyzed by SDS-PAGE and immuno-

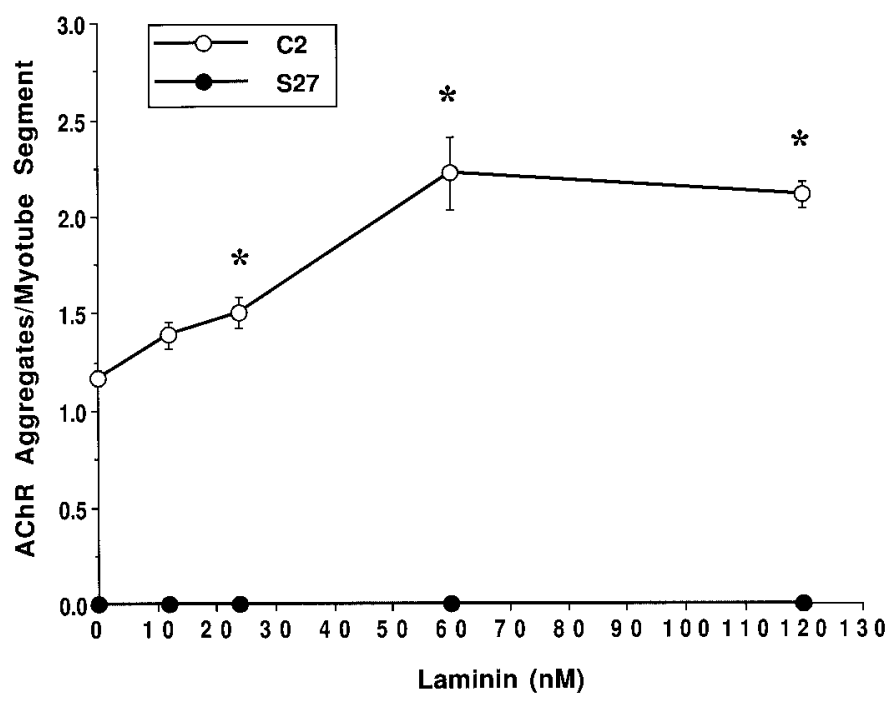

Figure 3. LN induces AChR aggregation in $\mathrm{C} 2$ but not $\mathrm{S} 27$ cells. Cultures were treated for $18 \mathrm{hr}$ with $0,12,24,60$, or $120 \mathrm{nM} \mathrm{LN}$, labeled with rhodamine-conjugated $\alpha$-bungarotoxin, and the number of AChR aggregates per myotube segment was quantified. Data points represent the mean \pm SEM of four experiments. For each experiment, 10 fields taken at random from each of four coverslips were quantified. $\mathrm{LN}$ induces the first significant increase in the number of AChR aggregates in $\mathrm{C} 2$ cells (open circles) at a concentration of $24 \mathrm{~nm}$. The response saturates at $60 \mathrm{~nm}$ with a twofold increase in the number of AChR aggregates over control. An asterisk indicates numbers of $\mathrm{LN}$-induced AChR clusters that are statistically significant from control as assessed by ANOVA and Fisher's test $(p<0.05)$. In contrast, no AChR aggregates were present in S27 cultures ( filled circles) at any concentration of LN tested. 


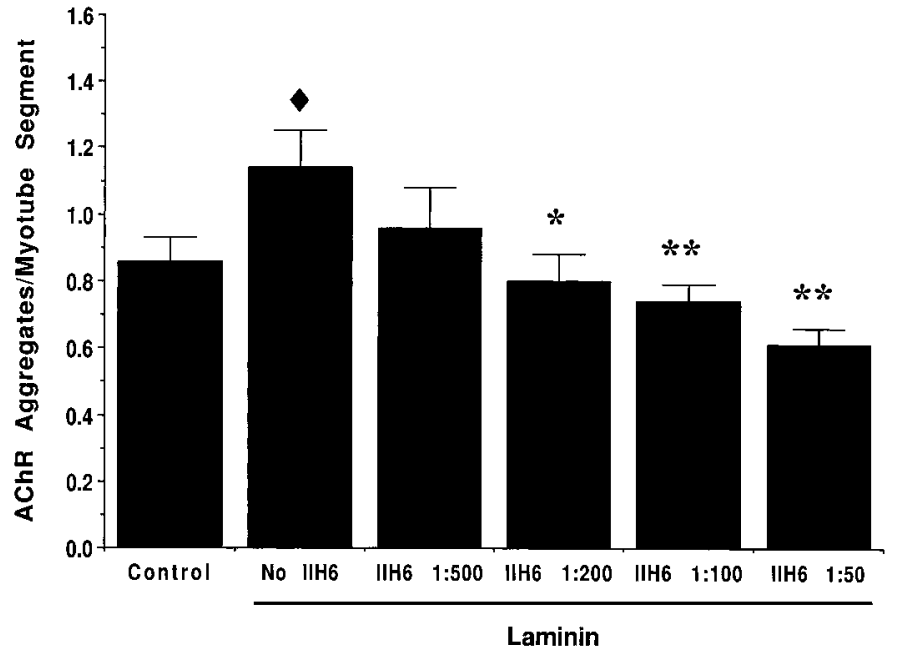

Figure 4. mAb IIH6 against $\alpha$-DG inhibits LN-induced AChR aggregation. Cultures of $\mathrm{C} 2$ myotubes were incubated for $18 \mathrm{hr}$ in medium alone (control) or in medium containing $48 \mathrm{nM} \mathrm{LN}$ and increasing concentrations of mAb IIH6 against $\alpha$-DG. For each condition, the number of AChR aggregates per myotube segment was determined for three experiments. For each experiment, 10 fields taken at random from each of three to four coverslips were quantified. At this concentration, LN induced an $\sim 30 \%$ increase in the number of AChR aggregates per myotube segment compared with control ( filled diamond, $p<0.01$ ). mAb IIH6 significantly decreased the number of AChR aggregates compared with LN treatment in a dose-dependent manner at dilutions as high as 1:200 (*, $p<0.01 ; * *$, $p<0.001)$. Although treatment with high concentrations of mAb IIH6 decreased the number of AChR aggregates below spontaneous levels, this decrease was not statistically significant. Values represent means \pm SEM, and significant differences from control ( filled diamond) or from LN-treated $(*)$ cultures were determined by ANOVA followed by Fisher's test.

blotting with a monoclonal anti-phosphotyrosine antibody (4G10). Blots were then stripped and reprobed with mAb 124 to the AChR $\beta$ subunit or with anti-MuSK antiserum to verify the identity of the phosphorylated bands (data not shown). Treatment of $\mathrm{C} 2$ myotubes with $200 \mathrm{pm}$ neural agrin leads to a rapid phosphorylation of MuSK ( $110 \mathrm{kDa}$; Fig. $7 A)$. However, treatment with LN did not induce MuSK phosphorylation, even at concentrations that induce maximal aggregation (Fig. 3B). Agrin also induced a robust increase in tyrosine phosphorylation of an $\sim 50 \mathrm{kDa}$ band that corresponds in size to the AChR $\beta$ subunit (Fig. $7 B$ ). In contrast, concentrations of $\mathrm{LN}$ that are sufficient to induce maximal aggregation do not phosphorylate the AChR $\beta$ subunit above endogenous levels seen in untreated cultures (Fig. $7 B)$. We conclude that the observed effects of LN on the size and number of AChR aggregates do not involve phosphorylation of either MuSK or the AChR $\beta$ subunit.

\section{DISCUSSION}

The formation of the postsynaptic apparatus of the skeletal neuromuscular junction is a complex process involving ECM, membrane, and cytoskeletal elements (for review, see Hall and Sanes, 1993; Carbonetto and Lindenbaum, 1995). Agrin released from nerve terminals activates MuSK to trigger events within muscle that lead to the aggregation of AChRs in the postsynaptic membrane. Diffusely distributed AChRs on the muscle cell surface first form loose assemblies of microaggregates beneath the nerve terminal that later coalesce into large aggregates (Anderson and Cohen, 1977; Steinbach, 1981). The results presented here sug-

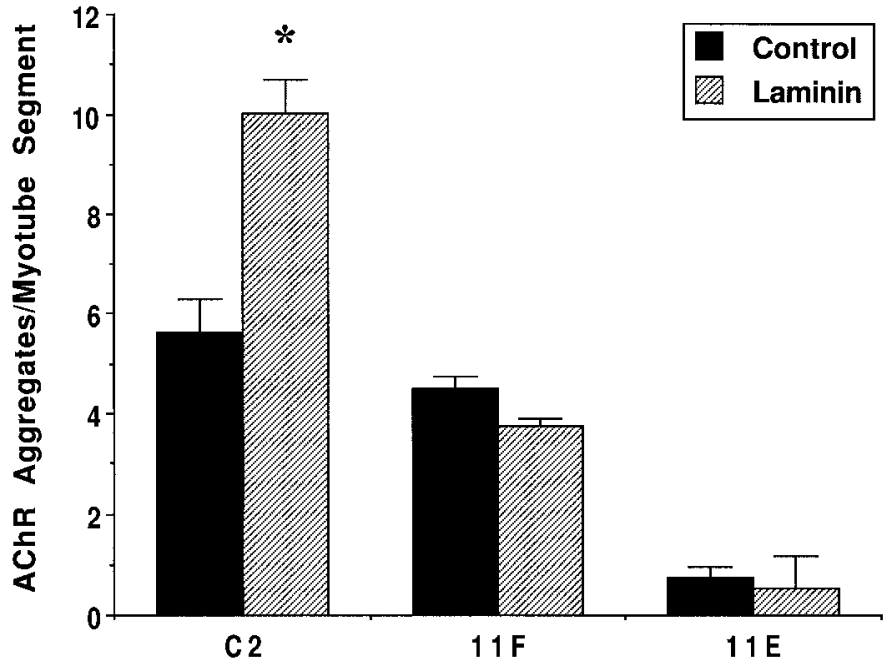

Figure 5. DG-antisense clones fail to aggregate AChRs in response to $\mathrm{LN} .11 \mathrm{~F}$ and $11 \mathrm{E}$ cells show reductions in $\alpha-\mathrm{DG}$ expression of 50 and $80 \%$, respectively, compared with parental C2 cells. Cells were treated for $18 \mathrm{hr}$ with $60 \mathrm{~nm} \mathrm{LN}$ and labeled with rhodamine-conjugated $\alpha$-bungarotoxin, and the number of AChR aggregates per myotube segment was quantified. LN (hatched bars) induced a twofold increase in AChR aggregates in $\mathrm{C} 2$ cells compared with control nontreated cultures (filled bars). However, both $11 \mathrm{~F}$ and $11 \mathrm{E}$ cells were unresponsive to $\mathrm{LN}$, indicating that $\alpha-\mathrm{DG}$ is necessary for $\mathrm{LN}$-induced $\mathrm{AChR}$ aggregation. Values represent means $\pm \mathrm{SD}$ of two coverslips from one representative experiment; 15-20 fields for each of the two coverslips per treatment and per cell type were quantified. Data from two separate experiments were not pooled because of variability in the level of spontaneous AChR aggregates in $\mathrm{C} 2$ cells. An asterisk indicates a statistically significant difference between control and LN treatment within each cell type ( $p<$ $0.05, t$ test).

gest that $\mathrm{LN}$ is important in the later stages of this process and that it acts through $\alpha$-DG via a MuSK-independent mechanism.

Our results extend previous data (Vogel et al., 1983) on LN stimulation of AChR aggregation by demonstrating a role for $\mathrm{LN}$ in determining the size and density of AChR aggregates. LN-rich regions are coextensive with a majority, but not all, of spontaneous and agrin-induced AChR aggregates. In untreated C2 myotubes, $81 \%$ of spontaneous aggregates are closely associated with LN. This value agrees well with results obtained in an earlier study in which $70-90 \%$ of spontaneous receptor aggregates in chick myotube cultures colocalized with LN (Bayne et al., 1984). Agrin causes a dramatic change in the distribution of LN on the cell surface, reflected by the twofold increase in AChR aggregates that overlap completely with LN. In addition, we show that treatment of cultures with agrin and an anti-LN antiserum leads to the formation of AChR microaggregates with an apparent lower AChR density, consistent with the notion that endogenous LN is necessary for their cohesion. These observations could suggest that the recruitment of $\mathrm{LN}$ at the nascent neuromuscular synapse by agrin might assist the latter in forming a continuous densely packed AChR aggregate under the nerve terminal. Indeed, microaggregates formed in the presence of the anti-LN antiserum resemble those seen in the early stages of AChR aggregation at neuromuscular synapses forming in vivo (Steinbach, 1981) and at synapses between neurites and myotubes in vitro (Anderson and Cohen, 1977; Kidokoro et al., 1980; Role et al., 1985). Microaggregates are also observed at initial stages of AChR aggregation induced by bath-applied agrin, where AChR microaggregates $\left(<4 \mu \mathrm{m}^{2}\right)$ begin forming within 1-2 hr of adding 


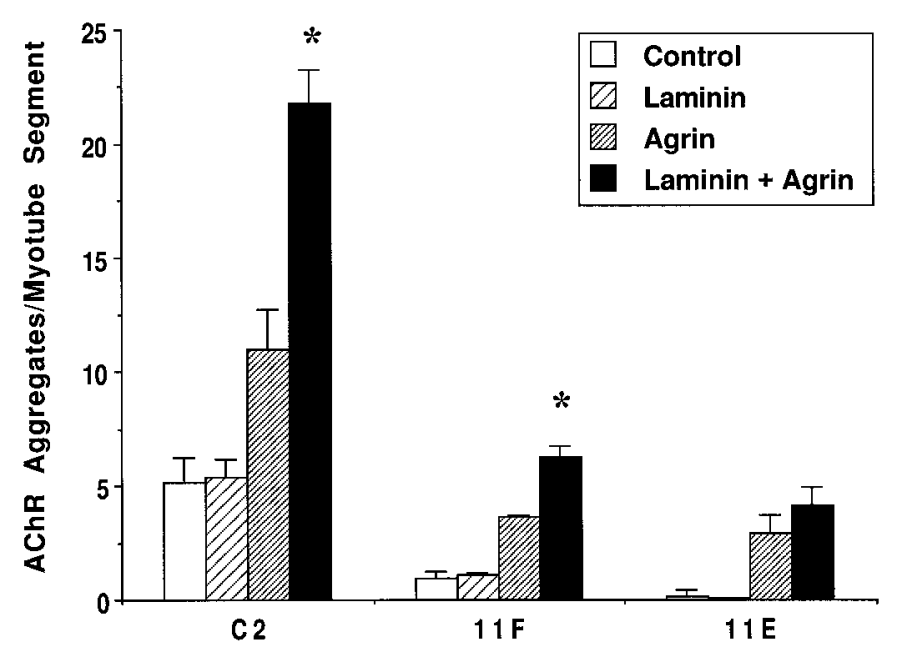

Figure 6. LN potentiates the AChR aggregating activity of agrin via its interaction with $\alpha$-DG. Cells were treated with $12 \mathrm{nM} \mathrm{LN}$ (wide hatched bars), $100 \mathrm{pm}$ agrin ( fine hatched bars), or both (filled bars) for $18 \mathrm{hr}$, and the number of AChR aggregates per myotube segment was quantified as described in Materials and Methods. The concentration of LN used is subthreshold and does not affect the number of AChR aggregates compared with control cultures (open bars) for all cell types. LN enhances the effect of agrin by twofold and 1.7-fold in $\mathrm{C} 2$ and $11 \mathrm{~F}$ cells, respectively. However, in $11 \mathrm{E}$ cells, where the $\alpha$-DG level is only $20 \%$ of that in $\mathrm{C} 2$ cells, LN does not significantly enhance the effect of agrin. Note that in both DG-antisense clones agrin alone induces AChR aggregation. Values represent means \pm SD for two experiments. For each experiment, 15-20 fields from each of two coverslips were quantified. An asterisk indicates a statistically significant difference between agrin and agrin $+\mathrm{LN}$ treatment within each cell type $(p<0.05, t$ test).

agrin to chick myotubes in culture (Godfrey et al., 1984; Wallace, 1988). Larger aggregates $\left(>4 \mu \mathrm{m}^{2}\right)$ are seen at later times (12-20 hr) and are formed in part by lateral migration and fusion of pre-existing microaggregates (Wallace, 1988). During this time, the total area occupied by AChR aggregates and their density increase. Similarly, we find that AChR aggregates induced by LN exhibit an increased size and density compared with their agrininduced counterparts. These observations support a model in which LN promotes the fusion of microaggregates into larger, more densely packed aggregates. However, they do not eliminate the possibility that LN stabilizes large aggregates once they have formed and that the anti-LN antiserum leads to the dispersal of these preformed macroaggregates.

In $\mathrm{C} 2$ cells, $\mathrm{LN}$ induces $\mathrm{AChR}$ aggregation in a dosedependent manner with a maximal effect at $60 \mathrm{~nm}$. In our hands, LN first shows a significant effect on AChR aggregation at $24 \mathrm{~nm}$; however Vogel et al. (1983) reported an effect with only $1.2 \mathrm{~nm}$ LN. One possible explanation for this difference could be the presence of small amounts of agrin in the $\mathrm{LN}$ preparation used by Vogel et al. (1983). Coomassie blue and silver staining of our purified LN revealed only a broad band at $\sim 200 \mathrm{kDa}$ and a second band at $\sim 400 \mathrm{kDa}$ corresponding to the $\beta / \gamma$ and $\alpha$ chains of LN, respectively (Montanaro and Carbonetto, unpublished observations). We further tested the purity of our LN by immunoblot with antibodies to agrin and LN $\alpha 2$ chain (merosin) and found that neither of these proteins was present (Montanaro and Carbonetto, unpublished observations). Alternatively, this observed difference may derive from the different types of cells used and from a relative weak response of $\mathrm{C} 2$ cells to exogenous $\mathrm{LN}$ compared with primary myotube cultures and G8-1 cells.

Agrin-induced AChR aggregation has been shown to require

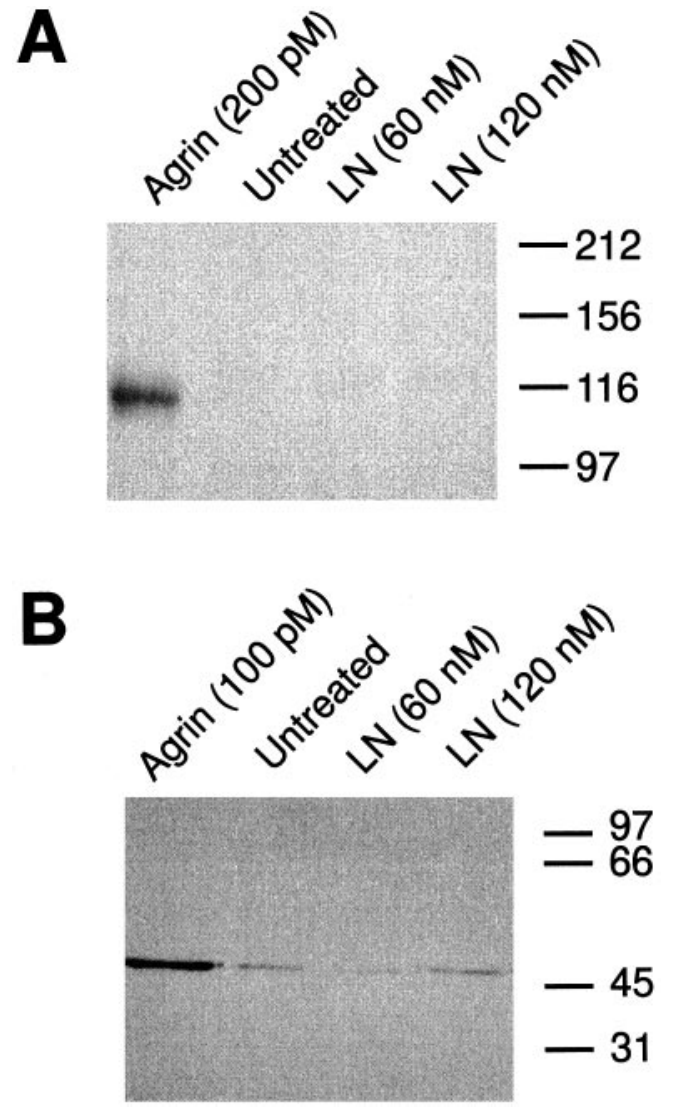

Figure 7. LN does not induce the phosphorylation of MuSK and the AChR $\beta$ subunit. C2 myotubes were treated for $15 \mathrm{~min}$ with the indicated concentrations of neural agrin or LN; then AChRs or MuSK were purified from the cell extracts (see Materials and Methods). The isolates were analyzed by SDS-PAGE, transferred to nitrocellulose, and then assayed for phosphotyrosine content by immunoblotting with mAb 4G10. $A$, Anti-phosphotyrosine immunoblot of MuSK immunoprecipitates. Treatment of $\mathrm{C} 2$ myotubes with $200 \mathrm{pm}$ agrin produced a large increase in MuSK phosphorylation compared with endogenous levels. LN, on the other hand, failed to induce MuSK phosphorylation at either of the two concentrations tested. $B$, Anti-phosphotyrosine immunoblot of purified AChR subunits. A prominent band at $\sim 50 \mathrm{kDa}$, corresponding in size to the AChR $\beta$ subunit, is evident in AChR isolates from cells treated with $100 \mathrm{pm}$ agrin. In contrast, treatment of $\mathrm{C} 2$ myotubes with either 60 or 120 nM LN did not induce the phosphorylation of the AChR $\beta$ subunit above the level seen in untreated cells. Molecular mass standards are indicated at the right of each panel (in $\mathrm{kDa}$ ).

activation of the tyrosine kinase receptor MuSK and to lead to the phosphorylation of the AChR $\beta$ subunit. Subsequent identification, cloning, and functional studies of MuSK (Valenzuela et al., 1995; DeChiara et al., 1996; Glass et al., 1996) indicated that its activation is responsible for initiating virtually all events in presynaptic and postsynaptic differentiation (DeChiara et al., 1996). Our studies indicate that LN-induced AChR aggregation does not involve the phosphorylation of either MuSK or the AChR $\beta$ subunit, even at concentrations that induce maximal receptor aggregation. We would therefore predict that phosphorylation inhibitors or a lack of MuSK would have no effect on this process in vitro. The complete lack of AChR aggregates in MuSK null mice indicates that in vivo $\mathrm{LN}$ and agrin do not induce the aggregation of AChRs via parallel pathways. Instead we envisage a model in which LN acts downstream of agrin-induced MuSK activation to potentiate the action of agrin and to consolidate AChR microaggregates into larger aggregates or to stabilize 
microaggregates within the forming subsynaptic receptor "plaque."

While this paper was being reviewed, Sugiyama et al. (1997) published a paper showing that LN 1, but not LN 2 or LN 11, induces AChR clustering in a muscle cell line derived from MuSK knock-out mice, although at a 20-fold lower level than that in C2 cells (DeChiara et al., 1996). In addition, they demonstrated that $\mathrm{LN}$-induced AChR aggregation occurs at a much slower rate than does agrin-induced AChR aggregation. Like us, they concluded that $\mathrm{LN}$ induces the aggregation of AChRs via a pathway that does not involve MuSK signaling but that in vivo activation of MuSK is required to initiate AChR aggregation. Furthermore, they find that the aggregating activity of $\mathrm{LN}$ is determined by the identity of its $\alpha$ chain. Our results complement and extend those of Sugiyama et al. (1997) by implicating $\alpha$-DG as the receptor that mediates this MuSK-independent aggregation. $\alpha$-DG is known to bind specifically to $\mathrm{G}$ domains in the $\mathrm{LN} \alpha$ chain (Gee et al., 1993) but is known to bind with similar affinity to LN 1 and LN 2 (Yamada et al., 1994, 1996). The unique ability of LN 1 to induce AChR aggregation could result from modulation of $\mathrm{LN}$ binding to $\alpha$-DG by heparan sulfate proteoglycans. Indeed heparin has been shown to modulate differentially the interaction of LN 1 and LN 2 to $\alpha$-DG (Pall et al., 1996). Alternatively, the LN $\alpha 2$ chain is much more prone to proteolysis than is the $\alpha 1$ chain during purification (Leivo and Engvall, 1988; Ehrig et al., 1990), and this can result in loss of the $\mathrm{G}$ domains and a loss of binding to $\alpha$-DG. This could explain the reported inability of purified LN 2 to induce AChR aggregation and would further support our observations that $\alpha$-DG mediates this aggregation.

Our data indicate that the effects of agrin and LN on $\mathrm{C} 2$ cells may not be mediated by integrins but rather involve the dual agrin and $\mathrm{LN}$ receptor $\alpha$-DG. First, $\alpha$-DG is immunocytochemically localized at AChR aggregates where LN appears concentrated, and it is the only protein detected in overlays of $\mathrm{C} 2$ myotube extracts probed with LN (Gee et al., 1994). Second, the $K_{\mathrm{d}}$ for LN binding to $\alpha$-DG ( $\sim 90 \mathrm{~nm}$; Gee et al., 1993) is close to the concentration of $\mathrm{LN}$ that induces half-maximal aggregation on $\mathrm{C} 2$ myotubes $(\sim 30 \mathrm{~nm})$. Third, S27 cells do not aggregate AChRs in response to $\mathrm{LN}$. Although these cells synthesize normal amounts of LN and deposit it into the ECM, they do not retain LN on their surfaces (Gordon et al., 1993). Consistent with this observation, the binding of $\mathrm{LN}$ to $\alpha$-DG is dramatically decreased in S27 myotube extracts compared with C2 extracts (Campanelli et al., 1994; Gee et al., 1994; Sugiyama et al., 1994). Moreover, the amount of full-size $\alpha$-DG is greatly reduced in S27 cells (Sugiyama et al., 1994). Thus, a reduction in $\alpha$-DG levels or in its affinity for LN may be responsible for the inability of S27 cells to retain $\mathrm{LN}$ on their surfaces and to aggregate AChRs in response to exogenous LN. Fourth, mAb IIH6 against $\alpha$-DG blocks LNinduced receptor aggregation in a dose-dependent manner. This antibody inhibits the binding of both $\mathrm{LN}$ and agrin to $\alpha$-DG and has been reported previously to interfere with agrin-induced AChR aggregation (Campanelli et al., 1994; Gee et al., 1994; Cohen et al., 1995; but see Sugiyama et al., 1994). Interestingly, in our hands, mAb IIH6 and the anti-LN antiserum had different effects on AChR aggregation, the former affecting the number of aggregates and the latter their size and number. This difference could be attributable to the fact that in $\mathrm{C} 2$ myotubes mAb IIH6 interferes with $\alpha$-DG binding to $\mathrm{LN}$ and muscle agrin, which could also be involved in AChR aggregation. Finally, we have found that two C2-derived cell lines transfected with antisense DG cDNA and expressing reduced levels of $\alpha$-DG do not show significant AChR aggregation in response to LN. $11 \mathrm{~F}$ and $11 \mathrm{E}$ cells show a specific decrease in $\alpha$-DG expression with levels 50 and $20 \%$ of parental C2 cells, respectively. Like S27 cells, both $11 \mathrm{~F}$ and $11 \mathrm{E}$ cells show an abnormal $\mathrm{LN}$ deposition on their surface (Lindenbaum, Montanaro, and Carbonetto, unpublished observations) and a decreased response to agrin (Jacobson, Montanaro, Lindenbaum, Carbonetto, and Ferns, unpublished observations). Taken together, these data suggest a role of $\alpha$-DG in $\mathrm{LN}$-induced AChR aggregation. In addition, we have shown that a subthreshold concentration of $\mathrm{LN}$ can significantly potentiate the AChR aggregating activity of recombinant neural agrin, providing further evidence of a cooperation between $\mathrm{LN}$ and agrin in AChR aggregation. As for LN-induced AChR aggregation, this synergistic effect of $\mathrm{LN}$ on agrin also seems to be mediated by $\alpha$-DG because it was not observed in $11 \mathrm{E}$ cells that have the lowest level of $\alpha$-DG expression.

Experiments of others have emphasized the presence of integrins at the NMJ in vivo and at AChR aggregates in culture (Bozyczko et al., 1987; Anderson et al., 1996; Belkin et al., 1996). Although we are unaware of any perturbation experiments with the function-blocking antibodies used for localization (Bozyczko et al., 1987) this precise colocalization suggests that integrins are involved in aggregation and makes them a potential candidate for mediating the effects of LN on muscle cells. Somewhat surprisingly however, we have found a poor localization of integrins in agrin-induced AChR aggregates on C2 myotubes. The antibody used in these experiments is directed against the $\beta 1$ subunit that is common to most, if not all, integrin LN receptors. This antiserum recognizes the extracellular domain of the $\beta 1$ subunit and should therefore cross-react with the two cytoplasmic splice variants $\beta 1_{\mathrm{A}}$ and $\beta 1_{\mathrm{D}}$ recently identified in skeletal muscle and $\mathrm{C} 2$ cells. In particular, $\beta 1_{\mathrm{D}}$ was localized to the $\mathrm{NMJ}$, where it is believed to act as a $\mathrm{LN}$ receptor by dimerizing with the $\alpha 7$ subunit. We have no definite explanation for the low colocalization of integrins with agrin-induced AChR aggregates in $\mathrm{C} 2$ cells. However, in all previous studies, AChR aggregation in culture was induced by either cocultured neurons or extracts containing full-length agrin. It is therefore possible that recruitment of integrins to AChR aggregates requires additional nerve-derived factors not present in our culture system or agrin domains not present in our recombinant agrin fragment. Further experiments with full-length agrin and function-blocking anti-integrin antibodies are required to address this issue.

How does LN stimulate the formation of large densely packed AChR aggregates? Previous studies have shown that LN can self-polymerize in solution via domains at the end of each of its short arms (Yurchenco et al., 1990; Colognato-Pyke et al., 1995) and forms an independent network in basement membranes (Yurchenco et al., 1992). Thus, one possibility is that LN selfassociates into a multimeric structure and in so doing "traps" AChR microaggregates at sites of assembly. A similar mechanism has been proposed by Cohen et al. (1997) to mediate the aggregation of $\alpha$-DG, $\beta$-DG, and dystrophin by exogenous $\mathrm{LN}$ in Xenopus myocytes. Interestingly, this aggregation is not blocked by inhibitors of tyrosine phosphorylation. Similarly, exogenous LN causes the aggregation of $\alpha$-DG on C2 myotubes (Lindenbaum, Montanaro, and Carbonetto, unpublished observations). Although there is no evidence of a direct interaction of LN with the AChR, expression of $\alpha$ - and $\beta$-DG together with rapsyn in nonmuscle cells results in a coclustering of these proteins (Apel et al., 1995). $\beta$-DG could therefore interact with rapsyn that is able to aggregate AChRs when expressed in nonmuscle cells (Froeh- 
ner et al., 1990; Phillips et al., 1991; Maimone and Merlie, 1993; Scotland et al., 1993). Hence, the aggregation of $\alpha / \beta$-DG complexes by $\mathrm{LN}$ in muscle cells may cause aggregation of AChRs via rapsyn by a MuSK-independent mechanism.

During synapse formation, the binding of agrin to MuSK would activate rapsyn and initiate aggregation of AChRs, MuSK, and $\alpha$-DG as well as LN bound to $\alpha$-DG. The local increase in the concentration of LN may potentiate direct interactions between LN-LN as well as LN-agrin (Denzer et al., 1997) molecules and lead to the coalescence of microaggregates of AChRs into large dense aggregates similar to those found at mature synapses.

\section{REFERENCES}

Anderson MJ, Cohen MW (1977) Nerve-induced and spontaneous redistribution of acetylcholine receptors on cultured muscle cells. J Physiol (Lond) 268:757-773.

Anderson MJ, Qiao Shi Z (1996) Proteolytic disruption of lamininintegrin complexes on muscle cells during synapse formation. Mol Cell Biol 16:4972-4984.

Apel ED, Roberds SL, Campbell KP, Merlie JP (1995) Rapsyn may function as a link between the acetylcholine receptor and the agrinbinding dystrophin-associated glycoprotein complex. Neuron 15:115-126.

Bayne EK, Anderson MJ, Fambrough DM (1984) Extracellular matrix organization in developing muscle: correlation with acetylcholine receptor aggregates. J Cell Biol 99:1486-1501.

Belkin AM, Zhidkova NI, Balzac F, Altruda F, Tomatis D, Maier A, Tarone G, Koteliansky VE, Burridge K (1996) $\beta 1 D$ integrin displaces the $\beta 1 \mathrm{~A}$ isoform in striated muscles: localization at junctional structures and signalling potential in nonmuscle cells. J Cell Biol 132:211-226.

Bevan S, Steinbach JH (1977) The distribution of alpha-bungarotoxin binding sites of mammalian skeletal muscle developing in vivo. J Physiol (Lond) 267:195-213.

Bozyczko D, Decker C, Muschler J, Horwitz AF (1989) Integrin on developing and adult skeletal muscle. Exp Cell Res 183:72-91.

Campanelli JT, Roberds SL, Campbell KP, Scheller RH (1994) A role for dystrophin-associated glycoproteins and utrophin in agrin-induced AChR clustering. Cell 77:663-674.

Carbonetto S, Lindenbaum M (1995) The basement membrane at the neuromuscular junction: a synaptic mediatrix. Curr Opin Neurobiol 5:596-605

Cohen MW, Jacobson C, Godfrey EW, Campbell KP, Carbonetto S (1995) Distribution of alpha-dystroglycan during embryonic nervemuscle synaptogenesis. J Cell Biol 129:1093-1101.

Cohen MW, Jacobson C, Yurchenco PD, Morris GE, Carbonetto S (1997) Laminin-induced clustering of dystroglycan on embryonic muscle cells: comparison with agrin-induced clustering. J Cell Biol 136:1047-1058

Collo G, Starr L, Quaranta V (1993) A new isoform of the laminin receptor integrin $\alpha 7 \beta 1$ is developmentally regulated in skeletal muscle. J Biol Chem 268:19019-19024.

Colognato-Pyke H, O'Rear JJ, Yamada Y, Carbonetto S, Cheng YS, Yurchenco PD (1995) Mapping of network-forming, heparin-binding, and alpha 1 beta 1 integrin-recognition sites within the alpha-chain short arm of laminin-1. J Biol Chem 270:9398-9406.

Daniels MP, Vigny M, Sonderegger P, Bauer HC, Vogel Z (1984) Association of laminin and other basement membrane components with regions of high acetylcholine receptor density of cultured myotubes. Int J Dev Neurosci 2:87-99.

DeChiara TM, Bowen DC, Valenzuela DM, Simmons MV, Poueymirou WT, Thomas S, Kinetz E, Compton DL, Rojas E, Park JS, Smith C, DiStefano PS, Glass DJ, Burden SJ, Yancopoulos GD (1996) The receptor tyrosine kinase MuSK is required for neuromuscular junction formation in vivo. Cell 85:501-512.

Denzer AJ, Brandenberger R, Gesemann M, Chiquet M, Ruegg MA (1997) Agrin binds to the nerve-muscle basal lamina via laminin. J Cell Biol 137:671-683.

Douville PJ, Harvey WJ, Carbonetto S (1988) Isolation and partial characterization of high affinity laminin receptors in neural cells. J Biol Chem 263:14964-14969.

Ehrig K, Leivo I, Argraves WS, Ruoslahti E, Engvall E (1990) Merosin, a tissue-specific basement membrane protein, is a laminin-like protein. Proc Natl Acad Sci USA 87:3264-3268.

Ervasti JM, Campbell KP (1991) Membrane organization of the dystrophin-glycoprotein complex. Cell 66:1121-1131.

Ervasti JM, Campbell KP (1993) A role for the dystrophin-glycoprotein complex as a transmembrane linker between laminin and actin. J Cell Biol 122:809-823.

Ferns MJ, Campanelli JT, Hoch W, Scheller RH, Hall Z (1993) The ability of agrin to cluster AChRs depends on alternative splicing and on cell surface proteoglycans. Neuron 11:491-502.

Ferns M, Deiner M, Hall Z (1996) Agrin-induced acetylcholine receptor clustering in mammalian muscle requires tyrosine phosphorylation. J Cell Biol 132:937-944.

Fertuck HC, Salpeter MM (1974) Localization of acetylcholine receptor by ${ }^{125}$ I-labeled alpha bungarotoxin binding at mouse motor endplates. Proc Natl Acad Sci USA 71:1376-1378.

Froehner SC, Luetje CW, Scotland PB, Patrick J (1990) The postsynaptic $43 \mathrm{~K}$ protein clusters muscle nicotinic acetylcholine receptors in Xenopus oocytes. Neuron 5:403-410.

Gee SH, Blacher RW, Douville PJ, Provost PR, Yurchenco PD, Carbonetto S (1993) Laminin-binding protein 120 from brain is closely related to the dystrophin-associated glycoprotein, dystroglycan, and binds with high affinity to the major heparin-binding domain of laminin. J Biol Chem 268:14972-14980.

Gee SH, Montanaro F, Lindenbaum MH, Carbonetto S (1994) Dystroglycan- $\alpha$, a dystrophin-associated glycoprotein, is a functional agrin receptor. Cell 77:675-686.

Glass DJ, Bowen DC, Stitt TN, Radziejewski C, Bruno J, Ryan TE, Gies DR, Shah S, Mattsson K, Burden SJ, DiStefano PS, Valenzuela DM, DeChiara TM, Yancopoulos GD (1996) Agrin acts via a MuSK receptor complex. Cell 85:513-523.

Godfrey EW, Nitkin RM, Wallace BG, Rubin LL, McMahan UJ (1984) Components of Torpedo electric organ and muscle that cause aggregation of acetylcholine receptors on cultured muscle cells. J Cell Biol 99:615-627.

Gordon H, Hall ZW (1989) Glycosaminoglycan variants in the C2 muscle cell line. Dev Biol 135:1-11.

Gordon H, Lupa M, Bowen D, Hall Z (1993) A muscle cell variant defective in glycosaminoglycan biosynthesis forms nerve-induced but not spontaneous clusters of the acetylcholine receptor and the $43 \mathrm{kDa}$ protein. J Neurosci 13:586-595.

Hall ZW, Sanes JR (1993) Synaptic structure and development: the neuromuscular junction. Cell [Suppl] 72:99-121.

Henry MD, Campbell KP (1996) Dystroglycan: an extracellular matrix receptor linked to the cytoskeleton. Curr Opin Cell Biol 8:625-631.

Hunter DD, Shah V, Merlie JP, Sanes JR (1989) A laminin-like adhesive protein concentrated in the synaptic cleft of the neuromuscular junction. Nature 338:229-234.

Hynes RO (1992) Integrins: versatility, modulation and signalling in cell adhesion. Cell 69:11-25.

Ibraghimov-Beskrovnaya O, Ervasti JM, Leveillle CJ, Slaughter CA, Sernett SW, Campbell KP (1992) Primary structure of dystrophinassociated glycoproteins linking dystrophin to the extracellular matrix. Nature 355:696-702.

Kidokoro Y, Anderson MJ, Gruener R (1980) Changes in synaptic potential properties during acetylcholine receptor accumulation and neurospecific interactions in Xenopus nerve-muscle cell culture. Dev Biol 78:464-483.

Leivo I, Engvall E (1988) Merosin, a protein specific for basement membranes of Schwann cells, striated muscle, and trophoblast, is expressed late in nerve and muscle development. Proc Natl Acad Sci USA 85:1544-1548.

Lieth E, Cardasis CA, Fallon JR (1992) Muscle-derived agrin in cultured myotubes: expression in the basal lamina and at induced acetylcholine receptor clusters. Dev Biol 149:41-54.

Maimone MM, Merlie JP (1993) Interaction of the $43 \mathrm{kDa}$ postsynaptic protein with all subunits of the muscle nicotinic acetylcholine receptor. Neuron 11:53-66.

Matsumura K, Ervasti JM, Ohlendieck K, Kahl SD, Campbell KP (1992) Association of dystrophin-related protein with dystrophin-associated proteins in $m d x$ mouse muscle. Nature 360:588-591.

Morissette N, Carbonetto S (1995) Laminin $\alpha 2$ chain (M chain) is found within the pathway of avian and murine retinal projections. J Neurosci 15:8067-8082.

Nitkin RM, Rothschild TC (1990) Agrin-induced reorganization of ex- 
tracellular matrix components on cultured myotubes: relationship to AChR aggregation. J Cell Biol 111:1161-1170.

Olek AJ, Ling A, Daniels MP (1986) Development of ultrastructural specializations during the formation of acetylcholine receptor aggregates on cultured myotubes. J Neurosci 6:487-497.

Olwin BB, Hall ZW (1985) Developmental regulation of laminin accumulation in the extracellular matrix of a mouse muscle cell line. Dev Biol 112:359-367.

Pall EA, Bolton KM, Ervasti JM (1996) Differential heparin inhibition of skeletal muscle $\alpha$-dystroglycan binding to laminins. J Biol Chem 271:3817-3821.

Phillips WD, Kopta C, Blount P, Gardner PD, Steinbach JH, Merlie JP (1991) ACh receptor-rich membrane domains organized in fibroblasts by recombinant 43-kilodalton protein. Science 251:568-570.

Qu Z, Huganir RL (1994) Comparison of innervation and agrin-induced tyrosine phosphorylation of the nicotinic acetylcholine receptor. J Neurosci 14:6834-6841.

Role LW, Matossian VR, O'Brien RJ, Fischbach GD (1985) On the mechanism of acetylcholine receptor accumulation at newly formed synapses on chick myotubes. J Neurosci 5:2197-2204.

Sanes JR, Engvall E, Butkowski R, Hunter DD (1990) Molecular heterogeneity of basal laminae: isoforms of laminin and collagen IV at the neuromuscular junction and elsewhere. J Cell Biol 111:1685-1699.

Scotland PB, Colledge M, Melnikova I, Dai Z, Froehner SC (1993) Clustering of the acetylcholine receptor by the $43 \mathrm{kDa}$ protein: involvement of the zinc finger domain. J Cell Biol 123:719-728.

Shadiack AM, Nitkin RM (1991) Agrin induces alpha-actinin, filamin, and vinculin to co-localize with AChR clusters on cultured chick myotubes. J Neurobiol 22:617-628.

Smalheiser NR, Schwartz NB (1987) Cranin, a laminin-binding protein of cell membranes. Proc Natl Acad Sci USA 84:6457-6461.

Song WK, Wang W, Foster RF, Bielser DA, Kaufman SJ (1992) H36- $\alpha 7$ is a novel integrin alpha chain that is developmentally regulated during skeletal myogenesis. J Cell Biol 117:643-657.

Steinbach JH (1981) Developmental changes in acetylcholine receptor aggregates at rat skeletal neuromuscular junctions. Dev Biol $84: 267-276$

Sugiyama JE, Bowen DC, Hall ZW (1994) Dystroglycan binds nerve and muscle agrin. Neuron 13:103-115.

Sugiyama JE, Glass DJ, Yancopoulos GD, Hall ZW (1997) Laminin- induced acetylcholine receptor clustering: an alternative pathway. J Cell Biol 139:181-191.

Tawil NJ, Houde M, Blacher R, Esch F, Reichardt LF, Turner DC, Carbonetto S (1990) $\alpha 1 \beta 1$ integrin heterodimer functions as a dual laminin/collagen receptor in neural cells. Biochemistry 29:6540-6544.

Timpl R, Rhode H, Risteli L, Ott U, Gehron Robey P, Martin GR (1982) Laminin. Methods Enzymol 82:831-839.

Turner DC, Flier LA, Carbonetto S (1989) Identification of a cellsurface protein involved in PC-12 cell-substratum adhesion and neurite growth on laminin and collagen. J Neurosci 9:3287-3296.

Valenzuela DM, Stitt TN, DiStefano PS, Rojas E, Mattsson K, Compton DL, Nunez L, Park JS, Stark JL, Gies DR, Thomas S, Le Beau MM, Fernald AA, Copeland NG, Jenkins NA, Burden SJ, Glass DJ, Yancopoulos GD (1995) Receptor tyrosine kinase specific for the skeletal muscle lineage: expression in embryonic muscle, at the neuromuscular junction, and after injury. Neuron 15:573-584.

Vogel Z, Christian CN, Vigny M, Bauer HC, Sonderegger P, Daniels MP (1983) Laminin induces acetylcholine receptor aggregation on cultured myotubes and enhances the receptor aggregation activity of a neuronal factor. J Neurosci 3:1058-1068.

Wallace BG (1988) Regulation of agrin-induced acetylcholine receptor aggregation by $\mathrm{Ca}^{++}$and phorbol ester. J Cell Biol 107:267-278.

Wallace BG (1989) Agrin-induced specializations contain cytoplasmic, membrane, and extracellular matrix-associated components of the postsynaptic apparatus. J Neurosci 9:1294-1302.

Wallace BG, Qu Z, Huganir RL (1991) Agrin induces phosphorylation of the nicotinic acetylcholine receptor. Neuron 6:869-878.

Yamada H, Shimizu T, Tanaka T, Campbell KP, Matsumura K (1994) Dystroglycan is a binding protein of laminin and merosin in peripheral nerve. FEBS Lett 352:49-53.

Yamada H, Chiba A, Endo T, Kobata A, Anderson LVB, Hori H, Fukuta-Ohi H, Kanazawa I, Campbell KP, Shimizu T, Matsumura K (1996) Characterization of dystroglycan-laminin interaction in peripheral nerve. J Neurochem 66:1518-1524.

Yurchenco PD, Cheng YS, Schittny JC (1990) Heparin modulation of laminin polymerization. J Biol Chem 265:3981-3991.

Yurchenco PD, Cheng YS, Colognato H (1992) Laminin forms an independent network in basement membranes. J Cell Biol [Erratum (1992) 118:493] 117:1119-1133. 